\title{
EDRIDGE-GREEN LECTURE COMPETITION AND COOPERATION IN VISUAL DEVELOPMENT
}

\author{
J. J. SLOPER \\ Nottingham
}

\begin{abstract}
SUMMARY
Studies of the effect of visual deprivation on cells in the lateral geniculate nucleus (LGN) show that there are two distinct sensitive periods in the monkey during which different reactions between the visual pathways related to the two eyes predominate and requirements for recovery from deprivation differ. The first extends from birth to about 8 weeks of age. The main interaction between the pathways from the two eyes is competitive, segregation of cortical ocular dominance columns occurs during this early period and monocular deprivation results initially in hypertrophy of undeprived LGN cells, with later parallel shrinkage of both deprived and undeprived parvocellular cells. Simply reopening the closed eye produces no recovery but reverse suture is effective in reversing some of the changes. The second sensitive period starts from about 8 weeks of age, although the peak of the later sensitivity appears to be at 7-9 months of age and some effect is still present at 12-18 months. During this later phase a cooperative interaction between the pathways related to the two eyes is necessary for normal development and in the absence of this selective shrinkage of both deprived and undeprived parvocellular LGN cells occurs. Simply reopening an eye during this late sensitive period allows recovery of these cells to normal size.
\end{abstract}

Visual disorders of early childhood occur in a visual system which is still undergoing development. They are influenced by this development and may influence its subsequent progress. This review describes experiments performed to investigate visual development in the primate and in particular the way in which the central visual pathways related to the two eyes interact during both normal and abnormal development. There is evidence that these interactions play an important role in the developmental process and understanding them should allow better

Correspondence to: Mr. J. J. Sloper, Department of Ophthalmology, University Hospital, Queen's Medical Centre, Nottingham NG7 2UH, UK. understanding and correction of childhood visual problems. The importance of such interactions in the causation and treatment of amblyopia has been emphasised in two clinical reviews. ${ }^{1,2}$

The effects of abnormal visual experience on development were first shown experimentally in the classical studies of Wiesel and Hubel in the cat. These showed that closure of one eye in kittens caused marked changes in the structure and function of the visual pathways. ${ }^{3,4}$ Three major changes were described. Firstly the eye became amblyopic; secondly the closed eye became much less effective in driving cells in the visual cortex which became dominated by inputs from the other, open eye; and thirdly neuronal cell bodies in the lateral geniculate nucleus (LGN) which received input from the closed eye shrank when compared with cells in the LGN laminae related to the open eye. These studies were the first demonstration that abnormal visual experience, in the absence of direct anatomical interference, had a marked effect on the development of the structure and function of the visual pathways and they introduced two important concepts. Firstly they showed that the development of the visual system was only affected by abnormal visual experience during a restricted period early in life: the critical or sensitive period. Secondly, because the closure of one eye has a much greater disruptive effect than the closure of both, they suggested that the changes produced by visual deprivation were due at least in part to a competitive interaction between the pathways related to the two eyes. ${ }^{5}$

The concept of competition in visual development was further investigated and developed by Guillery who studied the changes in LGN cell size produced by visual deprivation in kittens. He demonstrated that closure of both eyes had much less effect on LGN cell size than closure of one eye. ${ }^{6} \mathrm{He}$ also studied the cells in the LGN related to the extreme temporal visual field, which is monocular because there is no corresponding area of retina in the other eye. He showed that these LGN cells in the monocu- 


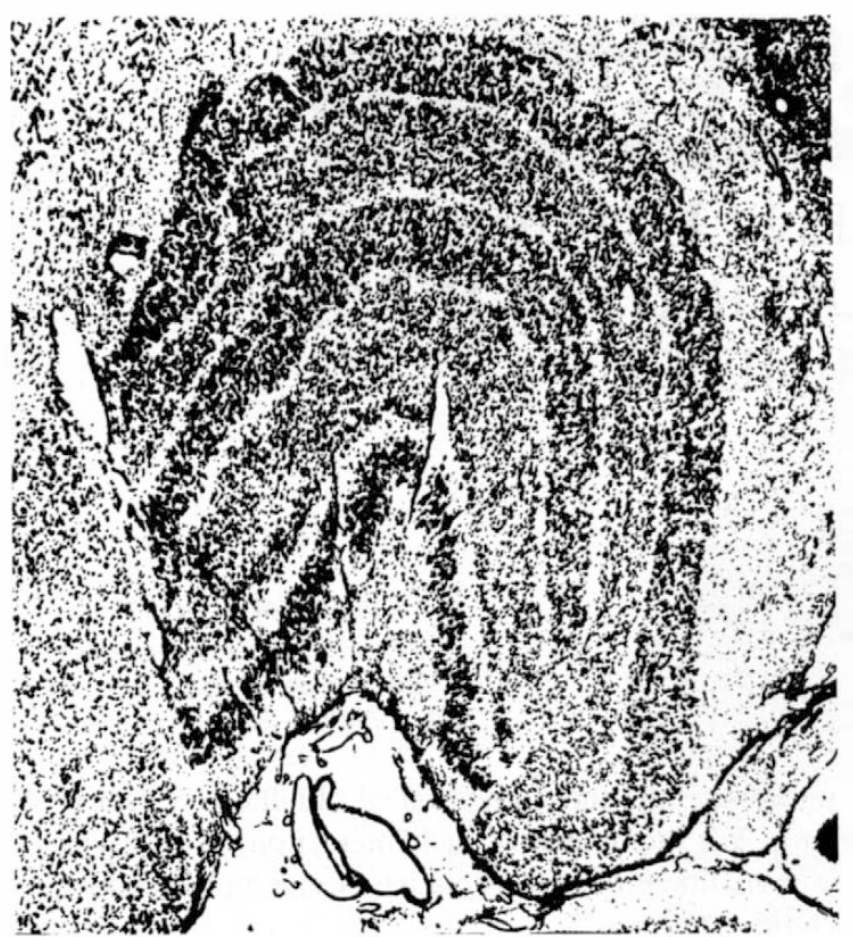

Fig. 1. Histological section of the lateral geniculate nucleus of an infant monkey after 34 days of closure of the ipsilateral eye started at birth. Cells in the deprived laminae 2, 3 and 5 (numbered from below) are smaller and paler than those in the undeprived laminae 1,4 and $6 . \times 27$.

lar segment did not shrink when their eye was closed although the cells receiving input from the same eye but in the binocular part of the same LGN lamina did. ${ }^{7}$ Thirdly he produced an artificial monocular segment by placing a small retinal lesion in one eye which denervated and caused transneuronal atrophy of the corresponding part of the LGN laminae related to that region of retina. When the other eye was then closed, cells in its LGN laminae shrank as expected, except in the artificial monocular segment opposite this denervated region. ${ }^{8}$ All these experiments showed that shrinkage of LGN cells only occurred when they were opposite a corresponding undeprived part of an LGN lamina related to the other eye. It was suggested that a competitive interaction played a part in causing the shrinkage and that this probably occurred at the axonal terminations of these cells in the visual cortex. ${ }^{5,7}$

Studies of the effects of visual deprivation on development were extended to the monkey by several groups. ${ }^{9-14}$ As in the cat, it was shown that monocular lid closure caused amblyopia, that the physiological responses of visual cortical neurons became dominated by the open eye and that deprived LGN cells became smaller than cells in the corresponding undeprived laminae (Fig. 1). The main period of sensitivity for these changes was the first 2-3 months of life, although a declining degree of sensitivity persisted for some time after this. The changes in size of LGN cells were measured by several authors and the results expressed as the percentage change in the projected area of deprived cells relative to cells in the corresponding undeprived lamina in the contralateral LGN of the same animal (Table I). The advantage of using each animal as its

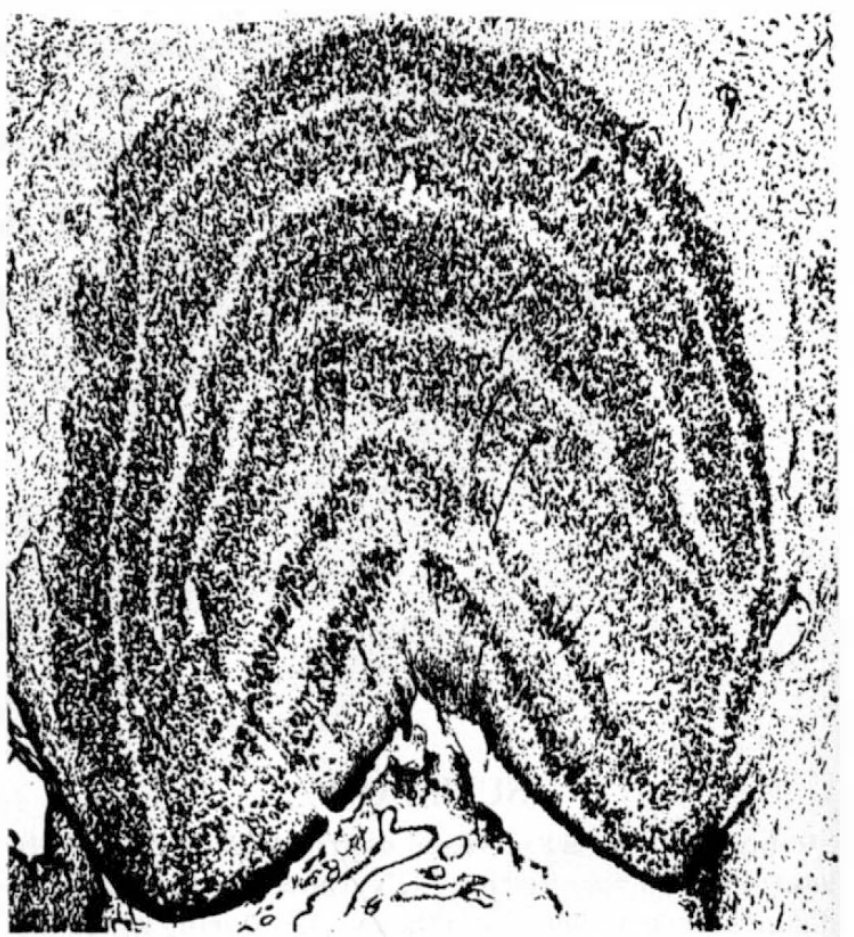

Fig. 2. Histological section of the lateral geniculate nucleus of a normal infant monkey. The magnocellular laminae 1 and 2 (below) contain larger cells than the parvocellular laminae 3-6 (above). If this figure is compared with Fig. 1 it can be seen in the experimental animal that it is the undeprived cells which have undergone hypertrophy rather than the deprived cells which have shrunk. $\times 27$.

own control in this way is that it minimises the effect of differences in cell size between different individuals, whether biological in origin or due to histological processing. It had in fact been thought that such differences were too large to allow reliable comparisons to be made between different animals. However, this method of analysis also assumes that the undeprived LGN cells are not affected by deprivation. For various reasons we came to question that assumption and made measurements of LGN cell size in a series of normal animals.

The appearance of the normal primate LGN is shown in Fig. 2. Laminae 1 and 2 are termed the magnocellular laminae because they contain larger cells than the small or

Table I. Mean cell areas $\left(\mu^{2}\right)$ for a sample of $50 \mathrm{LGN}$ cells from each LGN lamina for an infant monkey with one eye closed from day 1 to day 28 showing the relative shrinkage of deprived cells compared with undeprived cells.

\begin{tabular}{lccc}
\hline Lamina & Undeprived & Deprived & $\begin{array}{c}\text { \% change } \\
\text { deprived vs. } \\
\text { undeprived }\end{array}$ \\
\hline I & 357.4 & 284.5 & $-20^{* *}$ \\
II & 325.1 & 296.7 & $-9^{*}$ \\
III & 245.8 & 196.4 & $-20^{* *}$ \\
IV & 235.8 & 188.0 & $-20^{* *}$ \\
V & 248.9 & 189.2 & $-24^{* *}$ \\
VI & 228.3 & 183.9 & $-19^{* *}$ \\
\hline
\end{tabular}

${ }^{*} p<0.01 ; * * p<0.001$.

For clarity the standard deviations of each sample have been omitted, as in all the subsequent tables. These may be found in the original reports together with an explanation of the statistical methods used. ${ }^{15,16}$ 


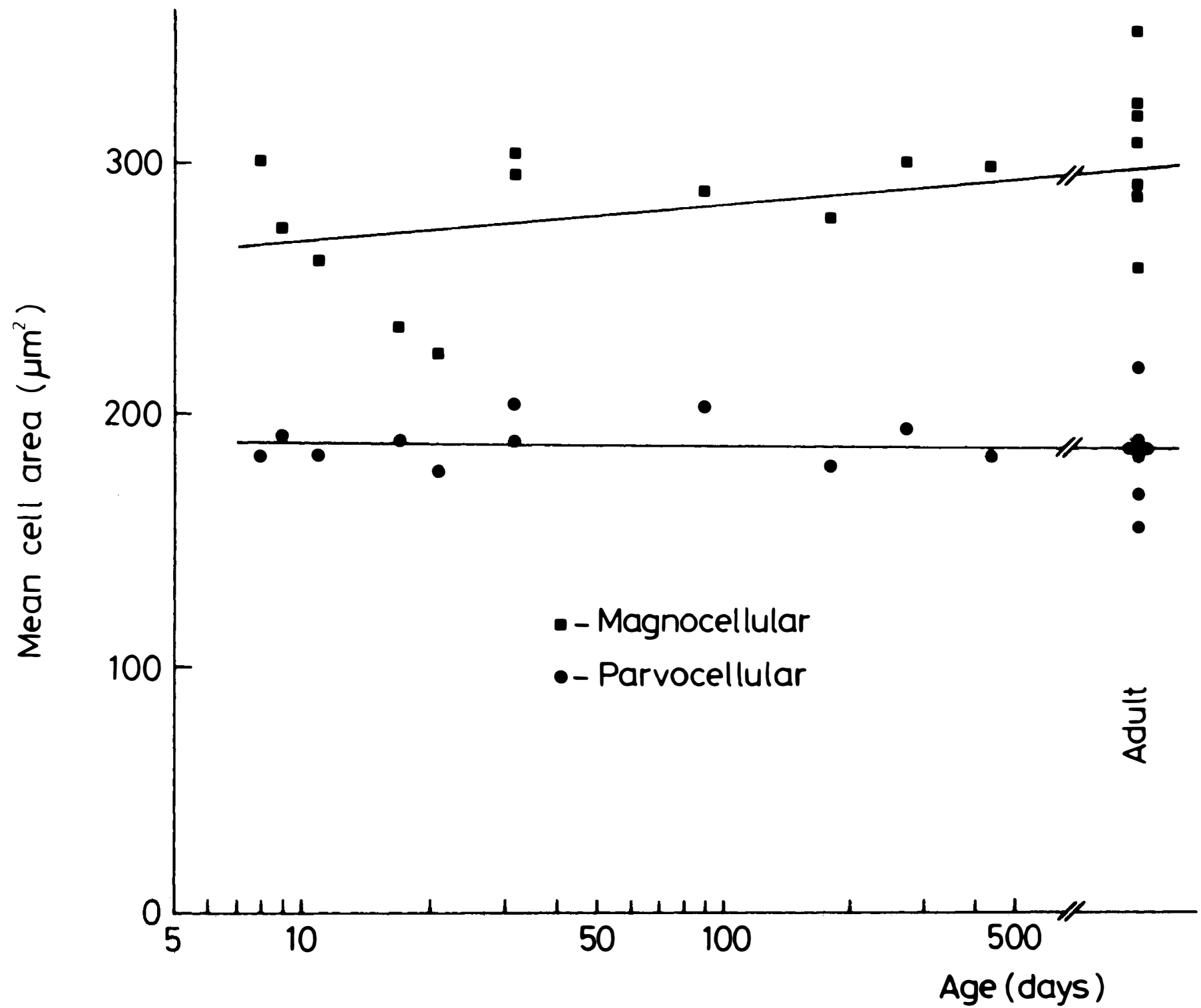

Fig. 3. The sizes of magnocellular and parvocellular LGN cells for 18 normal monkeys plotted using a logarithmic scale for age. Growth of parvocellular cells is complete by 1 week of age.

parvocellular laminae (3-6, laminae numbered from below). Laminae 1, 4 and 6 receive their input from the nasal retina of the contralateral eye and laminae 2, 3 and 5 from the temporal retina of the ipsilateral eye. A point in the visual field is represented by a line passing approximately perpendicularly through all six laminae. Measurements of cell size in a series of 18 normal animals showed that there was much less variability between different animals than had previously been thought. ${ }^{15}$ It also showed

Table II. Mean cell areas $\left(\mu \mathrm{m}^{2}\right)$ for each LGN lamina from a series of 18 normal monkeys ${ }^{15}$

\begin{tabular}{ll}
\hline Lamina & \\
\hline I & 294.0 \\
II & 291.5 \\
III & 195.7 \\
IV & 191.7 \\
V & 187.9 \\
VI & 181.8 \\
\hline
\end{tabular}

that growth of cells in the parvocellular LGN laminae was completed by 1 week of age; cells in the magnocellular laminae continued to grow but only by about $10 \%$ between infancy and adulthood (Fig. 3). These findings in the normal showed that it was possible to make reliable comparisons between different groups of animals and established a normal baseline from which to do this (Table

Table III. Mean cell areas $\left(\mu \mathrm{m}^{2}\right)$ for $50 \mathrm{LGN}$ cells from each lamina for the same animal with one eye closed from day 1 to day 28 as in Table I, but now compared with normal animals ${ }^{16}$

\begin{tabular}{lcccc}
\hline Lamina & Undeprived & $\begin{array}{c}\text { \% change } \\
\text { compared } \\
\text { with normal }\end{array}$ & Deprived & $\begin{array}{c}\% \text { change } \\
\text { compared } \\
\text { with normal }\end{array}$ \\
\hline I & 357.4 & +22 & 284.5 & -3 \\
II & 325.1 & +12 & 296.7 & +2 \\
III & 245.8 & +26 & 196.4 & 0 \\
IV & 235.8 & +23 & 188.0 & -2 \\
V & 248.9 & +32 & 189.2 & +1 \\
VI & 228.3 & +26 & 183.9 & +1 \\
\hline
\end{tabular}




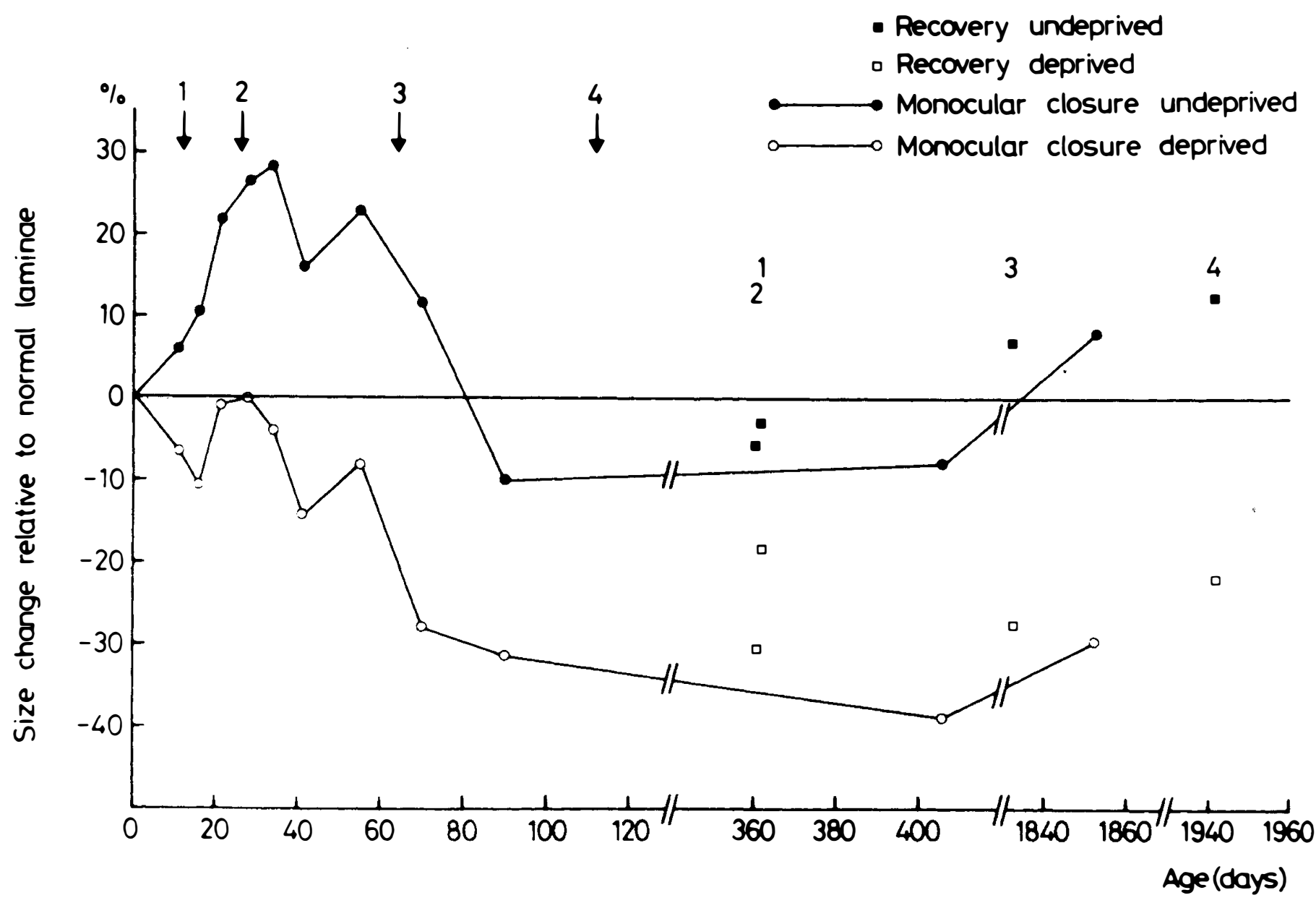

Fig. 4. The size change for both deprived and undeprived parvocellular LGN cells following monocular deprivation from birth. There is an initial hypertrophy of undeprived LGN cells followed by parallel shrinkage of both deprived and undeprived cells. Cell sizes plotted at 1,2,3 and 4 are from four further animals in which one eye was closed at birth and then reopened at the time indicated by the corresponding numbered arrow, in order to study recovery from deprivation. For animals 2 and 3 it can be seen that marked cell shrinkage occurred after reopening of the deprived eye.

II). The changes in cell size to be described in experimental animals have been analysed both by using comparisons between cells in deprived and undeprived laminae within experimental animals and also by comparing both deprived and undeprived cells in experimental animals with this normal baseline; this latter comparison produced some surprising conclusions.

The initial experiments were performed by closing the lids over one eye by a tarsorrhaphy which was performed under anaesthetic shortly after birth. After different periods, measurements were made of the cross-sectional area of 50 LGN cells from each lamina in sections prepared by a standard Nissl staining method. The appear- ance of the ipsilateral LGN after one eye had been closed for 34 days starting at birth is shown in Fig. 1. The cells in laminae 2, 3 and 5, connected to the closed eye, are smaller and paler than cells in the remaining laminae which received input from the open eye. Measurement of this size difference for a similar monkey shows the deprived cells to be about $30 \%$ smaller than the undeprived cells (Table I). It had been generally assumed that this represented either cell shrinkage or lack of growth of the deprived cells, in some way comparable to the transneuronal degeneration of LGN cells described following enucleation. Comparisons with normal animals showed surprisingly that this is not so. The deprived cells at this

Table I V. Mean cell areas $\left(\mu \mathrm{m}^{2}\right)$ for three monkeys with monocular closure from birth to between 90 days and 5 years ${ }^{16}$

\begin{tabular}{|c|c|c|c|c|c|}
\hline Lamina & Undeprived & $\begin{array}{l}\% \text { change compared } \\
\text { with normal }\end{array}$ & Deprived & $\begin{array}{l}\% \text { change compared } \\
\text { with normal }\end{array}$ & $\begin{array}{l}\% \text { change deprived } \\
\text { vs. undeprived }\end{array}$ \\
\hline I & $\begin{array}{l}321.3 \\
328.4\end{array}$ & $\begin{array}{l}+9^{*} \\
+13^{*}\end{array}$ & $\begin{array}{l}224.4 \\
221.2\end{array}$ & $\begin{array}{l}-24^{* *} \\
-24^{* *}\end{array}$ & $\begin{array}{l}-30 \\
-33\end{array}$ \\
\hline $\begin{array}{l}\text { III } \\
\text { IV } \\
\text { V } \\
\text { VI }\end{array}$ & $\begin{array}{l}187.9 \\
185.3 \\
183.9 \\
174.1\end{array}$ & $\begin{array}{l}-4 N S \\
-3 N S \\
-2 N S \\
-4 N S\end{array}$ & $\begin{array}{l}130.4 \\
132.7 \\
123.4 \\
119.0\end{array}$ & $\begin{array}{l}-33 * * * \\
-31 * * * \\
-34 * * * \\
-35 * * *\end{array}$ & $\begin{array}{l}-31 \\
-28 \\
-33 \\
-32\end{array}$ \\
\hline
\end{tabular}

NS, not significant; ${ }^{*} p<0.05 ; * * p<0.01 ; * * * p<0.001$. 


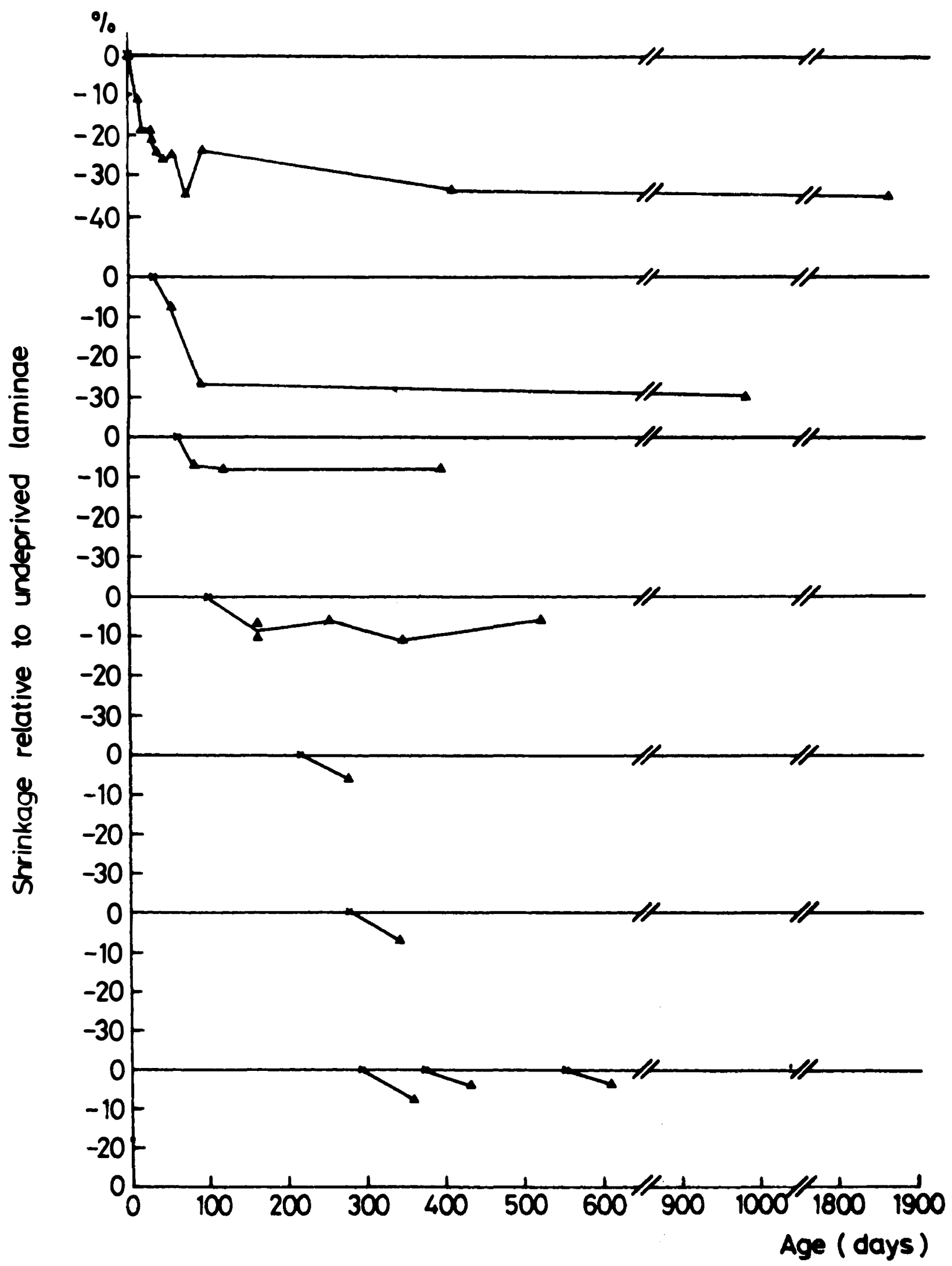

Fig. 5. The size difference between deprived and undeprived parvocellular cells for groups of monkeys with monocular closure started at progressively later ages. Much less effect is seen for closure started at 8 weeks of age or later (third and subsequent graphs). 


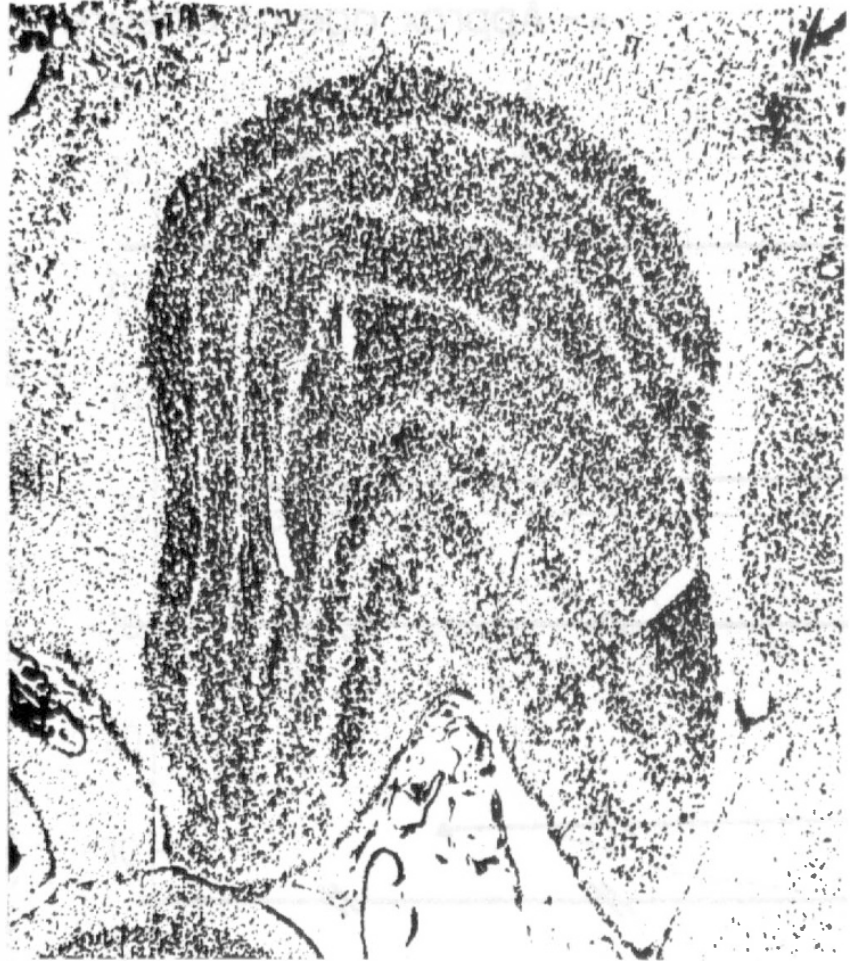

Fig. 6. Histological appearance of the LGN from an 11month-old monkey with monocular deprivation started at 9 months of age. Little effect of the closure is apparent, but measurements show marked shrinkage of both deprived and undeprived parvocellular cells. $\times 27$

time have in fact changed very little in size. The striking change in size is seen in the undeprived cells, which are larger than normal by about $25 \%$ (Table III). These cells have undergone hypertrophy in response to closure of the eye from which they did not receive connections. Results from a series of animals shows this hypertrophy to be well developed by 10 days of age and to persist until about 8 weeks of age (Fig. 4). Statistical analysis of these changes confirmed this surprising finding. ${ }^{16}$ The earliest and largest response to visual deprivation started at birth is hypertrophy of cells in the undeprived LGN laminae rather than shrinkage of deprived cells. It is the hypertrophy which is the major reason for the difference in size between deprived and undeprived cells in these animals.

The presence of a competitive interaction in the monkey had been demonstrated by Von Noorden who repeated Guillery's cat artificial monocular segment experiment and demonstrated a similar sparing of deprived cells opposite a region of denervated LGN lamina. ${ }^{17}$ That it is the cells related to the open eye which undergo the major initial size change described above confirms that an interaction between the visual pathways related to the two eyes plays an important part in these cell size changes since there has been no direct interference with the undeprived pathway. The axons of these LGN neurons pass through the optic radiation to the visual cortex where they arborise in layer IV and synapse with cortical neurons. At birth these axonal arborisations are spread evenly through layer IV, but over the first 3 weeks of life they become segregated to form the ocular dominance stripes. Alternate stripes contain axons related to each eye and the layer IV cells within each stripe are only driven by this eye. With normal development the stripes related to the two eyes segregate to form stripes of equal width, but following early monocular deprivation stripes related to the open eye are wider than normal and those from the deprived eye are narrower. ${ }^{12,13,18}$ It has been suggested that the normal segregation is due to a competitive mechanism and that during deprivation the undeprived axons are at a competitive advantage and retain a greater than normal territory. These enlarged axonal arborisations arise from undeprived LGN neurons and it is likely that their cell bodies undergo hypertrophy in response to this.

All the changes described above occur very early within about 8 weeks of birth in the monkey. The qualitative appearance of the LGN at much longer times after monocular closure from birth is very similar to Fig. 1 and the difference in cell size between deprived and undeprived cells changes very little after the first 4 weeks of closure. Because of this it had been assumed that little further change occurred following the establishment of this initial difference in cell size. However, this method of comparison hides a further phase of change which is only evident when deprived and undeprived cells are compared with normal cell sizes. Comparison with the normal baseline shows that after about 8 weeks of closure started from birth there is a second distinct phase of change. During this later phase both deprived and undeprived parvocellular LGN cells shrink markedly but in parallel (Fig. 4). Ultimately this results in the undeprived cells returning to normal size and the deprived cells shrinking to $30-40 \%$ smaller than normal (Table IV). The response to monocular closure started at birth thus occurs in two distinct phases. The major initial effect of closure at birth is to produce hypertrophy of the undeprived LGN cells. This is followed by a second phase characterised by parallel shrinkage of both deprived and undeprived LGN cells but restricted to the parvocellular laminae. Possible reasons for this second phase of change will be discussed below.

All the results described so far in relation to both changes in LGN cell size and changes in the visual cortex refer to closure of one eye started at the time of birth. If closure is started later, the monkey will have had a period of binocular visual experience prior to deprivation. By closing an eye at progressively later ages and comparing deprived with undeprived cells the sensitive period for deprivation can be delineated (Fig. 5). If an eye is closed at 3 weeks of age the size difference between deprived and undeprived cells is similar to that following closure at birth (Fig. 5, second curve; cf. top curve). If closure is delayed until 8 weeks of age, then the difference is much smaller even if the closure is prolonged (Fig. 5, third curve from top). A small effect is still seen with closure started at later ages up to a year to 18 months (Fig. 5, lower curves), but the major period of sensitivity as measured in this way is within the first 8 weeks or so. This is in general agreement with previous studies.

The histologial appearance of the LGN from a monkey 
Table V. Mean cell areas $\left(\mu \mathrm{m}^{2}\right)$ for a monkey with late monocular closure from day 275 to day 335

\begin{tabular}{|c|c|c|c|c|c|}
\hline Lamina & Undeprived & $\begin{array}{l}\% \text { change compared } \\
\text { with normal }\end{array}$ & Deprived & $\begin{array}{l}\% \text { change compared } \\
\text { with normal }\end{array}$ & $\begin{array}{c}\% \text { change deprived } \\
\text { vs. undeprived }\end{array}$ \\
\hline $\begin{array}{l}\text { I } \\
\text { II }\end{array}$ & $\begin{array}{l}230.3 \\
278.5\end{array}$ & $\begin{array}{l}-22 \\
-4\end{array}$ & $\begin{array}{l}245.8 \\
221.7\end{array}$ & $\begin{array}{l}-16 \\
-24\end{array}$ & $\begin{array}{l}+7 \mathrm{NS} \\
-20^{* *}\end{array}$ \\
\hline $\begin{array}{l}\text { III } \\
\text { IV } \\
\text { V } \\
\text { VI }\end{array}$ & $\begin{array}{l}155.3 \\
140.6 \\
137.5 \\
138.6\end{array}$ & $\begin{array}{l}-21 \\
-27 \\
-27 \\
-24\end{array}$ & $\begin{array}{l}138.8 \\
133.0 \\
137.0 \\
120.9\end{array}$ & $\begin{array}{l}-29 \\
-31 \\
-27 \\
-33\end{array}$ & $\begin{array}{l}-11^{*} \\
-5 \mathrm{NS} \\
0 \mathrm{NS} \\
-13^{*}\end{array}$ \\
\hline
\end{tabular}

NS, not significant; ${ }^{*} p<0.01 ; * * p<0.001$.

with a short period of monocular closure started much later, at 7 months of age, shows little effect of the closure (Fig. 6) and measurements of cell size show little consistent difference between cells in deprived and undeprived laminae (Table $\mathrm{V}$, right-hand column). This was as expected because it is well beyond the period of maximum sensitivity as described above. Comparison of the cell sizes in this monkey with those in normal monkeys, however, give a very different result. The cells in the deprived parvocellular laminae of this LGN are about $30 \%$ smaller than those in normal monkeys (Table V). The reason why this large change is not apparent is that the undeprived parvocellular cells are about $25 \%$ smaller than normal. A short period of monocular deprivation well outside the previously described sensitive period has produced changes in cell size which are as large, and occur as rapidly, as those following closure at birth, but they follow a different pattern, with both deprived and undeprived cells undergoing shrinkage and cells in the parvocellular laminae being affected selectively. If the data from the same animals as in Fig. 5 are replotted to show the changes in deprived and undeprived cell size separately in relation to normal cells it can be seen that the deprived cells shrink as much with closure started at 8 weeks of age and beyond as at birth (Fig. 7). What has been interpreted as the end of the sensitive period is not a reduction in sensitivity of the deprived cells to deprivation, but a masking of this shrinkage by a change in the reaction of the undeprived cells to closure. With closure at progressively later ages the deprived cells still undergo marked shrinkage but the response of the undeprived cells changes from hypertrophy following closure at birth, to shrinkage following closure started at 8 weeks of age or later. Analysis of data from 13 animals with late closure shows the statistical significance of these changes in both deprived and undeprived parvocellular cells and confirms that these changes do not affect cells in the magnocellular laminae (Table VI).

Why should cells receiving input from an open eye and at a supposed competitive advantage over the closed eye undergo shrinkage when deprivation is started at a later age? It was first suggested that normal activity of cells in the deprived parvocellular laminae might in some way interfere with the undeprived cells and cause them to shrink. ${ }^{19,20}$ Two experiments were performed to test this hypothesis. In the first of these, one eye was enucleated at 7 months of age. This produced marked transneuronal degeneration of the deafferented LGN cells directly connected to the enucleated eye as expected. It seems unlikely that these cells would then be able to interfere with the undeprived cells. However, clear-cut shrinkage of the undeprived parvocellular laminae comparable to that seen following late monocular deprivation still occurred in this animal. ${ }^{21}$ Measurements were also made of cells in the monocular segment of the LGN in the series of normal monkeys where no binocular interaction would be expected. Surprisingly these cells were found to shrink during normal development, unlike cells in the binocular parts of the same LGNs which maintain their size. ${ }^{22}$ These findings led to the suggestion that it was not interference during abnormal visual experience but the absence of a cooperative interaction present during normal visual development which leads to the shrinkage of both deprived and undeprived parvocellular LGN cells at these later ages. It appears that some form of active cooperation between the binocular parts of the pathways related to the two eyes occurs during the later part of normal development and it is in the absence of this that all parvocellular LGN cells shrink.

To return to the interpretation of the second phase of parallel shrinkage following closure at birth, there are striking similarities between the pattern of these later changes and the effects of closure started later. Both involve parallel shrinkage affecting both deprived and undeprived LGN cells and both selectively affect cells in the parvocellular laminae. The main difference is that the undeprived cells start their shrinkage from an initially hypertrophied state following closure at birth and this disparity in size between undeprived and deprived cells is maintained during the second phase of parallel shrinkage. It seems likely that the initial abnormalities caused by the early deprivation prevent subsequent cooperation and that the same mechanisms underlie the parallel shrinkage in both instances. This interpretation is confirmed by the results of reopening an eye closed at birth (see below).

The analysis of the changes in LGN cell size in relation to a normal baseline shows that the developing primate visual system passes through two distinct sensitive periods during which the patterns of change produced by deprivation are very different and during which the interaction between the pathways related to the two eyes changes fundamentally. During the first sensitive period from birth to about 8 weeks a competitive interaction predominates. The major initial effect of monocular closure 


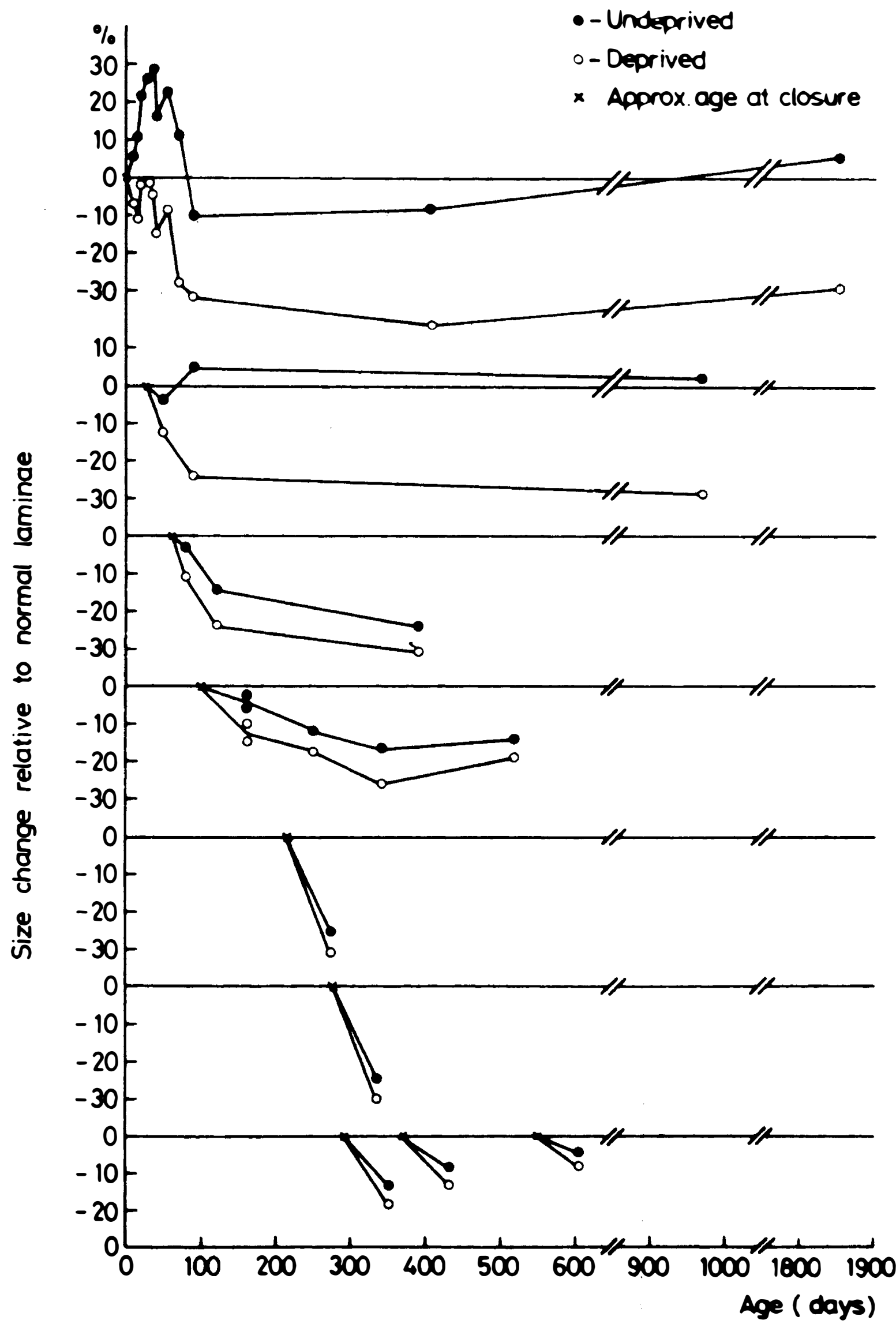

Fig. 7. Cell sizes from the same animals as in Fig. 5 but changes in undeprived and deprived cells relative to normal are now plotted separately. This shows that marked shrinkage of deprived parvocellular cells occurs following later closure but that this is masked by shrinkage of undeprived cells. 
Table VI. Mean cell areas $\left(\mu \mathrm{m}^{2}\right)$ for 13 monkeys with monocular closure started after 8 weeks of age ${ }^{16}$

\begin{tabular}{|c|c|c|c|c|c|}
\hline Lamina & Undeprived & $\begin{array}{l}\% \text { change compared } \\
\text { with normal }\end{array}$ & Deprived & $\begin{array}{l}\% \text { change compared } \\
\text { with normal }\end{array}$ & $\begin{array}{c}\% \text { change deprived } \\
\text { vs. undeprived }\end{array}$ \\
\hline $\begin{array}{l}\text { I } \\
\text { II }\end{array}$ & $\begin{array}{l}287.8 \\
299.3\end{array}$ & $\begin{array}{l}-2 \mathrm{NS} \\
+3 \mathrm{NS}\end{array}$ & $\begin{array}{l}280.7 \\
267.7\end{array}$ & $\begin{array}{l}-5 \mathrm{NS} \\
-8 \mathrm{NS}\end{array}$ & $\begin{array}{l}-2 \\
-11\end{array}$ \\
\hline $\begin{array}{l}\text { III } \\
\text { IV } \\
\text { V } \\
\text { VI }\end{array}$ & $\begin{array}{l}172.3 \\
165.1 \\
163.4 \\
158.1\end{array}$ & $\begin{array}{l}-12^{*} \\
-14^{*} \\
-13^{*} \\
-13^{*}\end{array}$ & $\begin{array}{l}158.9 \\
152.2 \\
151.4 \\
146.7\end{array}$ & $\begin{array}{l}-19^{*} \\
-21^{*} \\
-19^{*} \\
-19^{2}\end{array}$ & $\begin{array}{l}-8 \\
-8 \\
-7 \\
-7\end{array}$ \\
\hline
\end{tabular}

NS, not significant; ${ }^{*} p<0.001$.

at birth is hypertrophy of undeprived LGN cells and it is during this early period that the well-known segregation of cortical ocular dominance columns and their changes in width with deprivation occur. The late sensitive period extends from about 8 weeks to a year of age. During this time the predominant interaction between the pathways related to the two eyes is cooperative and monocular closure leads to shrinkage of both deprived and undeprived parvocellular LGN cells. Monocular closure during the late sensitive period has little, if any, effect on the relative widths of cortical ocular dominance columns in layer IV ${ }^{13}$ although it is possible that there are changes in axonal density within them. The monocularly driven cortical neurons in layer IV activate neurons in the more superficial and deeper cortical layers by way of intracortical connections and it is not until this stage that convergence between the inputs from the two eyes occurs in the primate to produce binocularly driven neurons. Late monocular deprivation has been shown to cause changes in physiologically determined ocular dominance confined to neurons in these layers outside layer IV $^{13,23}$ and also to produce changes in the cytochrome oxidase staining of these layers. ${ }^{24}$ It seems likely that the late LGN cell size changes reflect changes in cortical binocular function produced by deprivation, possibly acting either through intracortical connections back into layer IV or the extensive cortico-geniculate projection. Such binocular functions depend on connections which combine and analyse the input from the two eyes. If one eye is deprived then input from neither eye can be used in this way and the fact that both deprived and undeprived parvocellular cells shrink may be a reflection of this loss.

The existence of these two different sensitive periods during which different types of interaction are important has implications for experiments designed to try to reverse the effects of visual deprivation. Simply reopening the eye after early monocular deprivation has previously been shown not to produce any reduction in the size difference between deprived and undeprived LGN cells ${ }^{25-27}$ or to produce physiological recovery. ${ }^{18,25,28}$ Analysis of the changes in relation to normal cell sizes shows a more complex situation. Following monocular closure at birth the closed eye was reopened at successively later ages in a series of four animals (arrows, Fig. 4) and cell sizes measured after prolonged recovery periods. The sizes of LGN cells at the time of reopening can be inferred from the normal curve at the corresponding arrow and compared with the actual sizes plotted at the age of measurement. From this it can be seen that both deprived and undeprived cells in animals 2 and 3 underwent marked shrinkage after reopening of the closed eye. Not only was there no recovery, but the abnormality continued to develop in the same way as though the closure had been maintained. This means that the abnormalities produced by a short early period of monocular deprivation continue to prevent normal development even after the initial cause has been removed and that the abnormality produced during the first period is compounded by the consequential abnormal development during the second phase.

Because simply reopening the eye was not sufficient to produce recovery, experiments have been performed in which the initially open eye was closed at the same time, a manoeuvre termed reverse suture. This has been shown to abolish the difference in size between deprived and undeprived LGN cells ${ }^{14,26}$ and also to reverse the dominance of cortical cell responses by the initially open eye. ${ }^{28}$ However, comparisons with normal animals showed that, although the difference between initially deprived and initially undeprived LGN cells was abolished by reverse suture, the result was far from normal. ${ }^{29,30}$ Closure of one eye at birth produced hypertrophy of cells in the initially undeprived parvocellular laminae, with little change in the initially deprived cells. Reverse suture at 3 weeks of age caused subsequent hypertrophy of these latter cells which are now undeprived, with only a small reduction in the pre-existing degree of hypertrophy of the now deprived cells (Fig. 8). After a short period of reverse suture all parvocellular LGN cells are about $15 \%$ larger than normal, although the size difference between them is small.

The measurements above were all made within 8 weeks of birth, before the animal entered the second phase of developmental sensitivity. Further experiments were performed to explore long-term development in the second phase starting from this abnormal situation where all LGN cells were hypertrophied. ${ }^{30}$ In the first set of experiments the reverse sutured eye was kept closed after the same initial period of closure of the other eye. In the long term this resulted in shrinkage of all parvocellular cells from their hypertrophied state, but there was rather more shrinkage of the now deprived cells so that they were eventually markedly smaller than normal. A further group of experiments was performed to try to re-establish normal development by opening both eyes to allow binocular visual experience following reverse suture. In five 
Table VII. Summary of results for five animals with both eyes reopened following monocular closure at birth and reverse suture at 21 days of age $\mathrm{e}^{30}$

\begin{tabular}{lcllll}
\hline & $\begin{array}{c}\text { Length of } \\
\text { reopening } \\
\text { Animal }\end{array}$ & Eys) & Eye movements & Visual function & \multicolumn{2}{c}{$\begin{array}{c}\text { \% shrinkage of parvocellular cells } \\
\text { compared with normal }\end{array}$} \\
\hline OM 446 & 9 & Continuous nystagmus & Bilateral amblyopia & -8 & Initially undeprived \\
OM 437 & 9 & Divergent squint & R fixation, ?L amblyopia & -23 & -10 \\
OM 447 & 15 & Normal & R amblyopia & -7 & -30 \\
OM 429 & 15 & Normal & Normal & -24 & -2 \\
OM 462 & 36 & Divergent squint & Not tested & -23 \\
\hline
\end{tabular}

$\mathrm{R}$, right; L, left.

animals one eye was closed for 3 weeks from birth and then reverse suture was maintained for $1-5$ weeks before this second eye was also opened. The aim of these experiments was to equalise the size of initially deprived and undeprived LGN cells and then to open both eyes prior to the start of the second sensitive period at 8 weeks of age. The results from this group of animals are summarised in Table VII. In one animal cell sizes returned to normal, with eye movements and vision appearing normal. Two animals developed marked divergent squints, with all parvocellular LGN cells being markedly smaller than normal. One animal became bilaterally amblyopic with continuous nystagmus; parvocellular cells in this animal were about $10 \%$ smaller than normal, but larger than those in the two exotropes. Because of the variability of the outcome in this group of animals it is difficult to draw firm conclusions. It is clear, however, that small differences in timing were associated with major differences in outcome. The two best outcomes occurred after 15 days of reversal and this appeared to be the time at which the balance between the two eyes as judged by cell size had been restored most accurately. It is also important to note that, at these early ages, it was possible to cause amblyopia in the second eye without producing recovery of the initially amblyopic eye. A similar result has also been found in kittens. $^{31}$

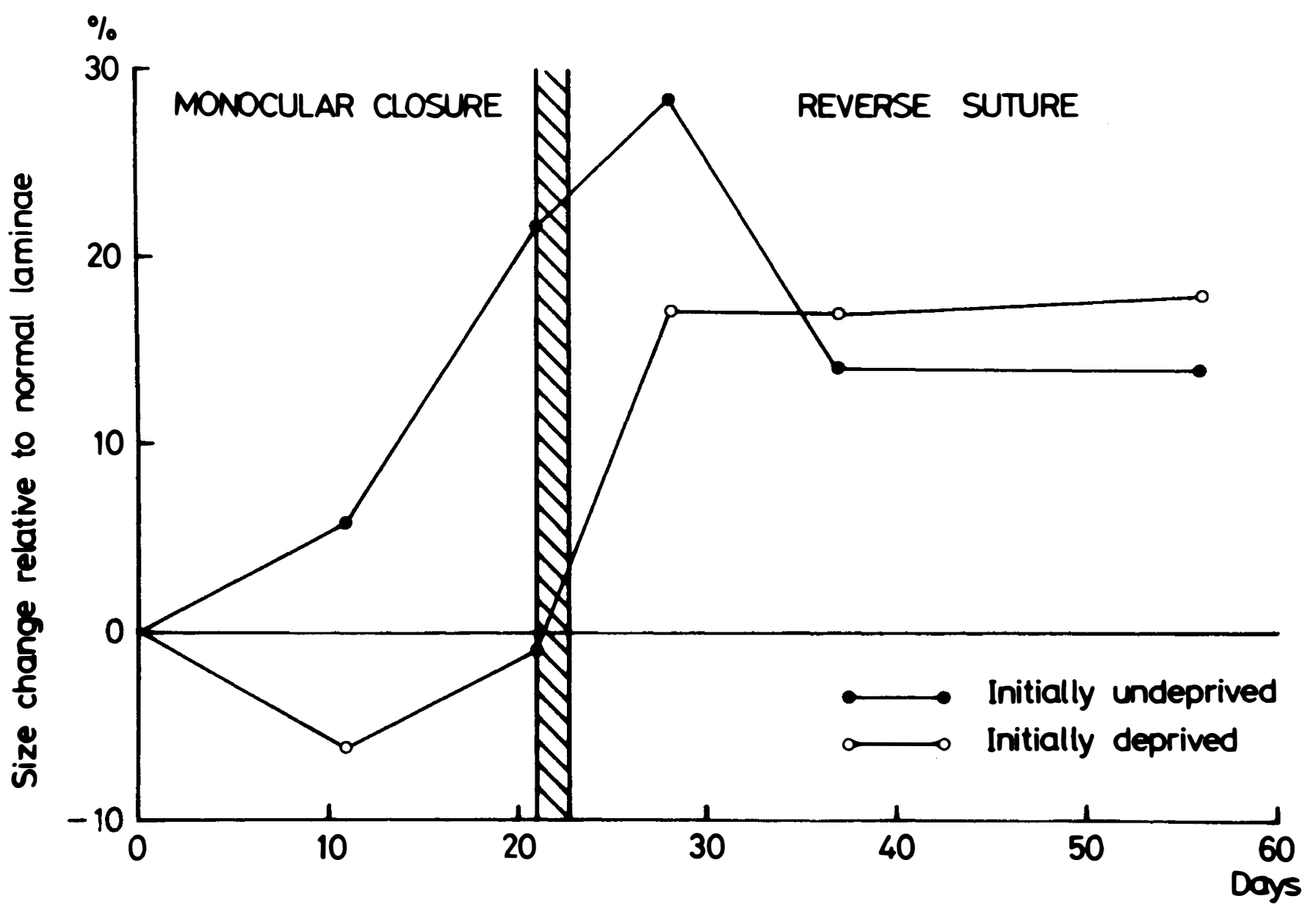

Fig. 8. Changes in size of parvocellular LGN cells following monocular closure at birth and reverse suture at 3 weeks of age. Hypertrophy of the initially undeprived cells is followed by hypertrophy of the initially deprived cells when they are put at a competitive advantage following reverse suture. 
The above group of experiments were all designed to study recovery from deprivation started at birth. Experiments were also performed to study recovery from deprivation started later, in the second sensitive period. Two animals were monocularly deprived from 7 to 9 months of age, and then the closed eye was simply reopened. This allowed recovery of both deprived and undeprived parvocellular cells to normal size without further intervention, although the small size difference between deprived and undeprived cells remained (Fig. 9).

In the reverse suture experiments it is of particular interest that the initially deprived cells underwent hypertrophy when they were put at a competitive advantage at 3 weeks of age by the opening of their eye and closure of the other eye (Fig. 8). When cells that have not been deprived are put at a similar advantage at the same age by monocular closure after 3 weeks of normal binocular vision they do not hypertrophy (Fig. 7). After 3 weeks of deprivation LGN cells are reacting as cells in a normal animal would react to closure at birth rather than closure at 3 weeks of age. This means that deprivation has caused the deprived cells to retain an abnormal degree of plasticity and has modified the interaction between the visual pathways related to the two eyes. An extended period of developmental sensitivity has also been described in cats which have been reared in total darkness. ${ }^{32}$ These results show that the duration of periods of developmental sensitivity determined by whether a normal visual system is affected by deprivation at a particular age do not necessarily apply to a visual system which has had abnormal visual experience, and it may not be possible to predict from the effects of closure in a normal animal how an animal of the same age with previous abnormal visual experience will react. It may well be that a similar retention of sensitivity plays an important role in the successful reversal of amblyopia, particularly with therapy started late.

Previous studies had concluded that visual deprivation caused shrinkage or lack of growth of deprived LGN cells and that this effect decreased with age, indicating the end of the sensitive period. By using normal animals as a baseline the present studies have shown a more complex situation, with both deprived and undeprived LGN cells changing in response to monocular deprivation and with different changes in the undeprived cells for deprivation started at different ages. These results show that there are two distinct sensitive periods in the monkey during which different mechanisms predominate and requirements for recovery differ. The first extends from birth to about 8 weeks of age. The main interaction between the pathways from the two eyes is competitive, segregation of cortical ocular dominance columns occurs during this early period and monocular deprivation results initially in hypertrophy of undeprived LGN cells, together with marked changes in ocular dominance columns. Simply reopening the closed eye produces no recovery but reverse suture is effective in reversing some of the changes, although the normal

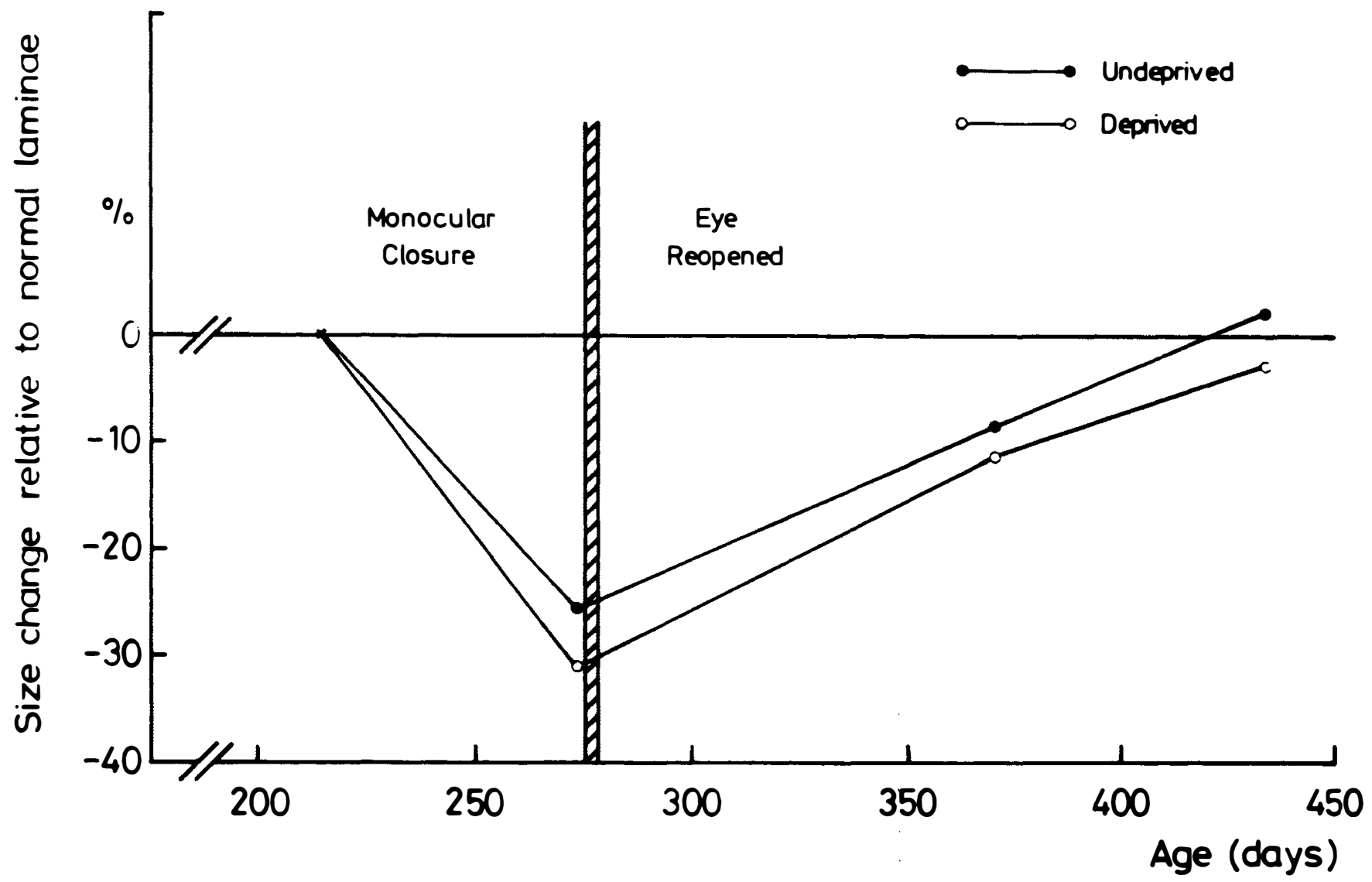

Fig. 9. The effect of reopening an eye 2 months after monocular closure started at 7 months of age. Parvocellular cells recover to almost normal size, although a small difference between deprived and undeprived cells remains. 
development of binocularity may not occur. The second sensitive period starts from about 8 weeks of age, although the peak of the later sensitivity appears to be at 7-9 months of age and some effect is still present at 12-18 months. During this later phase a cooperative interaction between the pathways related to the two eyes is necessary for normal development to occur and in the absence of this, selective shrinkage of both deprived and undeprived parvocellular LGN cells occurs. No change in cortical ocular dominance columns has been described following late closure, although there are cortical changes outside layer IV. Simply reopening an eye during this late sensitive period allows recovery of these cells to normal size, although this does not necessarily imply full functional recovery.

The generally accepted factor for converting ages in monkey to equivalent ages in man is 4 to $1 .{ }^{33}$ However, there are several pieces of anatomical evidence by which direct comparisons can be made between monkey and human data that all indicate the primate visual system is more mature than that of the human at the time of birth. In particular, cells in the human parvocellular LGN laminae continue to grow until 6 months of age, ${ }^{34}$ whereas growth is completed by 1 week of age at the latest in the monkey; ${ }^{15}$ LGN neurons show immature anatomical features at a later age in man than monkey; $; 3,36$ and cytochrome oxidase patches appear in the visual cortex of the monkey several weeks before birth, but only after birth in man. ${ }^{37}$ Together these findings indicate that the newborn monkey is probably at an equivalent stage of visual development to a 4- to 6-month-old baby. Taking this into account, the change from the early to late sensitive period in man would be predicted to occur at about a year to 18 months of age. Such extrapolations must, of course, be treated with considerable caution but would be in keeping with evidence for a peak sensitivity to binocular disruption at 2-3 years of age in $\operatorname{man}^{38,39}$ and clinical evidence that realignment of strabismics before the age of 2 years allows the best development of binocularity ${ }^{40}$ Although we have not attempted to determine whether our monkeys with late-onset deprivation become amblyopic, the demonstration of anatomical sensitivity at a much later age than previously thought may also help to resolve the apparent anomaly that children appeared to be sensitive to deprivation at a much later relative age than monkeys. ${ }^{41}$ It has been suggested on other grounds that there are separate critical periods for development of resolution acuity and stereopsis in man and also that there may be differential involvement of the magnocellular and parvocellular systems. ${ }^{42}$

The evidence that the human visual system is anatomically less mature at birth than that of the monkey is also of interest in relation to the evidence for a latent period of at least 6 weeks from birth before the onset of sensitivity to deprivation in man. ${ }^{41,43}$ There is such a latent period in the cat, which also has an anatomically immature visual system at birth ${ }^{44}$ but not in the monkey, in which deprivation effects occur within a few days of birth. This difference between monkey and man probably represents simply a difference in the timing of birth in relation to the developmental process rather than a fundamental difference in visual development. However, it is interesting that the monkey, which does not appear to develop congenital esotropia, is probably still in utero at an age equivalent to that at which this problem develops in man and so does not use its visual system until it is more fully developed.

Most previous animal work has concentrated on changes occurring in the early sensitive period. If development in monkey and man are similar then many children present with abnormalities of visual development starting in the second sensitive period. The present studies have shown that the same abnormality of visual experience starting at different ages may have very different effects on development of the visual system and require different conditions for recovery. It may well be that the mechanisms underlying the development of amblyopia of any type in the early and late sensitive periods are very different in both location and action. Finally it is important to remember that deprivation may extend developmental plasticity so that timing of sensitive periods as described above can only strictly be applied to a visual system which has previously undergone normal development.

I am grateful to Dr. T. P. S. Powell, FRS, of the Department of Human Anatomy, University of Oxford, who initiated these studies with Mr. M. P. Headon and in whose laboratory they were performed; I am pleased to acknowledge their collaboration throughout. I am also grateful to Dr. R. W. Hiorns of the Department of Biomathematics, University of Oxford, for assistance and advice with the statistical analysis. This work was supported by grants from the Medical Research Council and Wellcome Trust and I am grateful for the support of the Royal Society through an Alan Johnston, Lawrence and Moseley Research Fellowship.

I am grateful to the Royal College of Surgeons for giving me the opportunity to present this work.

Key words: Competition, Cooperation, LGN, Visual development.

\section{REFERENCES}

1. Von Noorden GK. Amblyopia: a multidisciplinary approach. Invest Ophthalmol Vis Sci 1985;26:1704-16.

2. Fells P. Amblyopia: an historical perspective. Eye 1990;4: 775-86.

3. Wiesel TN, Hubel DH. Effects of visual deprivation on morphology and physiology of cells in the cat's lateral geniculate body. J Neurophysiol 1963;26:978-93.

4. Wiesel TN, Hubel DH. Single cell responses in striate cortex of kittens deprived of vision in one eye. J Neurophysiol 1963;26:1003-17.

5. Wiesel TN, Hubel DH. Comparison of the effects of unilateral and bilateral eye closure on cortical responses in kittens. J Neurophysiol 1965;28:1029-40.

6. Guillery RW. The effect of lid suture upon the growth of cells in the dorsal lateral geniculate nucleus in kittens. $J$ Comp Neurol 1973;148:417-22.

7. Guillery RW, Stelzner DJ. The differential effects of unilateral lid closure upon the monocular and binocular segments of the dorsal lateral geniculate nucleus in the cat. $\mathrm{J}$ Comp Neurol 1970;139:413-22.

8. Guillery RW. Binocular competition in the control of geniculate cell growth. J Comp Neurol 1972;144:117-30.

9. Headon MP, Powell TPS. Cellular changes in the lateral 
geniculate nucleus of infant monkeys after suture of the eyelids. J Anat 1973;116:135-45.

10. Von Noorden GK. Experimental amblyopia in monkeys: further behavioral observations and clinical correlations. Invest Ophthalmol 1973;12:721-6.

11. Von Noorden GK. Histological studies of the visual system in monkeys with experimental amblyopia. Invest Ophthalmol Vis Sci 1973;12:727-38.

12. Hubel DH, Wiesel TN, LeVay S. Plasticity of ocular dominance columns in monkey striate cortex. Phil Trans R Soc [B] 1977;278:377-409.

13. LeVay S, Wiesel TN, Hubel DH. The development of ocular dominance columns in normal and visually deprived monkeys. J Comp Neurol 1980;191:1-51.

14. Vital-Durand F, Garey LJ, Blakemore C. Monocular and binocular deprivation in the monkey: morphological effects and reversibility. Brain Res 1978;158:45-64.

15. Headon MP, Sloper JJ, Hiorns RW, Powell TPS. Sizes of neurons in the primate lateral geniculate nucleus during normal development. Dev Brain Res 1985;18:51-6.

16. Headon MP, Sloper JJ, Hiorns RW, Powell TPS. Effects of monocular closure at different ages on deprived and undeprived cells in the primate lateral geniculate nucleus. Dev Brain Res 1985;18:57-78.

17. Von Noorden GK, Crawford MLJ, Middleditch PR. The effects of monocular visual deprivation: disuse or binocular interaction? Brain Res 1976;111:277-85.

18. Swindale NV, Vital-DurandF, Blakemore C. Recovery from monocular deprivation in the monkey. III. Reversal of anatomical effects in the visual cortex. Proc R Soc [B] 1981;213:435-50.

19. Headon MP, Sloper JJ, Hiorns RW, Powell TPS. Cell size changes in undeprived laminae of the monkey lateral geniculate nucleus after monocular closure. Nature 1979;281:572-4.

20. Headon MP, Sloper JJ, Hiorns RW, Powell TPS. Shrinkage of cells in undeprived laminae of the monkey lateral geniculate nucleus following late closure of one eye. Brain Res 1981;229:187-92.

21. Sloper JJ, Headon MP, Powell TPS. Effects of enucleation at different ages on the sizes of neurons in the lateral geniculate nucleus of infant and adult monkeys. Dev Brain Res 1987;31:259-65.

22. Sloper JJ, Headon MP, Powell TPS. Changes in the size of cells in the monocular segment of the primate lateral geniculate nucleus during normal development and following visual deprivation. Dev Brain Res 1987;31:267-76.

23. Blakemore C, Garey LJ, Vital-Durand F. The physiological effects of monocular deprivation and their reversal in the monkey's visual cortex. J Physiol (Lond) 1978;283: 223-62.

24. Horton JC. Cytochrome oxidase patches: a new cytoarchitectonic feature of monkey visual cortex. Phil Trans R Soc [B] 1984;304:199-254.

25. Von Noorden GK, Crawford MLJ. Morphological and physiological changes in the monkey visual system after short term lid suture. Invest Ophthalmol Vis Sci 1978; 17:762-8.

26. Garey LJ, Vital-Durand F. Recovery from monocular depri- vation in the monkey. II. Reversal of morphological effects in the lateral geniculate nucleus. Proc $R$ Soc [B] 1981;213:425-33.

27. Headon MP, Sloper JJ, Hiorns RW, Powell TPS. Effect of reopening an eye after a period of monocular deprivation on sizes of neurons in the primate lateral geniculate nucleus. Dev Brain Res 1985;18:57-78.

28. Blakemore C, Vital-Durand F, Garey LJ. Recovery from monocular deprivation in the monkey. I. Reversal of physiological effects in the visual cortex. Proc $R$ Soc $[B]$ 1981;213:399-423.

29. Sloper JJ, Headon MP, Powell TPS. Simultaneous hypertrophy of cells related to each eye in the lateral geniculate nucleus of the infant monkey following short term reverse suture. Dev Brain Res 1984;15:295-7.

30. Sloper JJ, Headon MP, Powell TPS. Experiments to study recovery of LGN cell size following lid closure and reverse suture in infant monkeys. Dev Brain Res 1988;40:47-59.

31. Murphy KM, Mitchell DE. Reduced visual acuity in both eyes of monocularly deprived kittens following a short or long period of reverse occlusion. J Neurosci 1987; 7:1526-36.

32. Cynader M. Prolonged sensitivity to monocular deprivation in dark-reared cats: effects of age and visual exposure. Dev Brain Res 1983;8:155-64.

33. Boothe RG, Dobson V, Teller DY. Postnatal development of vision in human and non-human primates. Annu Rev Neurosci 1985;8:495-545.

34. Hickey TL. Postnatal development of the human lateral geniculate nucleus: relationship to a critical period for the visual system. Science 1977;198:836-8.

35. Garey LJ, Saini KD. Golgi studies of the normal development of neurons in the lateral geniculate nucleus of the monkey. Exp Brain Res 1981;44:117-28.

36. De Courten C, Garey LJ. Morphology of neurons in the human lateral geniculate nucleus and their normal development. Exp Brain Res 1982;47:159-71.

37. Horton JC, Hedley-White ET. Mapping of cytochrome oxidase patches and ocular dominance columns in the human visual cortex. Phil Trans R Soc [B] 1984;304:255-272.

38. Banks MS, Aslin RN, Letson RD. Sensitive period for the development of human binocular vision. Science 1975; 190:675-7.

39. Hohmann A, Creutzfeldt OD. Squint and the development of binocularity in humans. Nature 1975;254:613-4.

40. Ing MR. Early surgical alignment for congenital esotropia. J Paediatr Ophthalmol Strabismus 1983;20:11-8.

41. Vaegan, Taylor D. Critical period for deprivation amblyopia in children. Trans Ophthalmol Soc UK 1979;99:432-9.

42. Atkinson J. Early visual development: differential functioning of parvocellular and magnocellular pathways. Eye 1992;6:129-35.

43. Elston JS, Timms C. Clinical evidence for the onset of the sensitive period in infancy. $\mathrm{Br} \mathrm{J}$ Ophthalmol 1992;76: 327-8.

44. Hubel DH, Wiesel TN. The period of susceptibility to the physiological effects of unilateral eye closure in kittens. J Physiol 1970;206:419-36. 